\title{
HOW TO ELIMINATE THE GAP BETWEEN THE WORLD OF ACADEMICIANS AND TEACHERS?
}

\author{
Milan Kubiatko \\ University of Zilina, Slovakia \\ E-mail: mkubiatko@gmail.com
}

I would like to thank the editor for the space to share my ideas about the selected problems of education. One of them is relative independence of college world and the world of elementary and high schools. There are in brief form described relative problems and suggested the possibilities how to solve them.

What is the importance of research studies focused on the education for teachers or for future teachers? It is a very actual question, because the activity of researchers on education should also aim on the teachers and future teachers. But in many countries the world of academicians (in this case we are focused on the academicians working in the faculties of education) is detached from the world of teaching and problems of teachers. So, there is another question. Why the cooperation between academicians and teachers in some countries is functional and in some countries these two worlds are living separately? The mistake could be found in the activity of academicians. Their activity should also be focused on the improving of learning and teaching. The academicians have got many activities. They are teaching, predominantly future teachers, they are writing manuscripts (as we all are hoping), they are attending conferences, where they are changing kinds of information with their colleagues from other faculties. They are writing proposals of grants. They are working administrative and other kinds of jobs for department and other activities.

Toward the first point, maybe there is the core of the problem, but only maybe. The teachers focused on the didactics of subjects, special pedagogy, social pedagogy, and other humanity subjects should connect theory with practice. But how is the reality? Many academicians have not got real practice form the education process. The subject didactics is taught by professors, who were not in the class as teachers. They have not got experience with this kind of teaching and learning. So, their seminars and lectures could lead to skewed view on the process of teaching. The academicians are forgetting on the cognitive skills of the pupils in elementary schools and also the students in high schools have got cognitive skills on the different level in comparison with the university students. Academicians could lecture things, which are unrealizable in the real conditions in the schools. When the future students, after finishing their studies at university, start to teach at schools, they will be surprised with the different conditions in the real world. And, due to this fact, they are starting to refuse kinds of information coming from universities and they consider it as untrue. And it can be the result, why the teachers at elementary and high schools have no interest in products, which are coming from universities.

The similar situation is in the field of academic writing. Academicians have the duty (many of them have not got an idea about this duty) to publish the results of their research. In many cases the academicians say: "We are bringing new ideas, which are not only for us, but they are for teachers". However, the teachers in mostly cases do not read the products of academicians. The reasons are different, for example too little time for reading of articles. But, 
Milan KUBIATKO. How to eliminate the gap between the world of academicians and teachers?

PROBLEMS

OF EDUCATION

IN THE $21^{\text {st }}$ CENTURY

Volume 67,2015

there is one reason, which is very important. The teachers in many cases show, that the kinds of information in the journals are not written in an understandable form for teachers. It can be true, because academicians do not write for teachers, their interest is to be successful in the methods of evaluation and also the academicians want to be cited. From the many views it is a correct approach, because many of the academicians are also researchers and they have got an effort to publish the results of the research in journals.

So, how to connect these two worlds, which are living separately. There are some possibilities how to solve this situation. The academicians could also write some studies for popular journals, which are primarily focused for teachers and the studies should be written in the form, which is understandable for teachers. But, there is one important thing, the authors of the studies should be people, who have got direct and real connection with the teaching process. The academicians should know, how to connect the kinds of information, which are the results of research with the needs of teachers. Because, relatively, there is a danger, if the authors are the academicians without any teaching practice, there is a possibility to lose the potential of the journal.

Also, there is a possibility to cooperate on some research projects, which connect the life of the academic environment with the real school environment, where both sides could use their own experiences.

The possibilities of cooperation are on many fronts and there is a big chance to connect these two worlds and it can lead to the quality process of teaching and learning. This process will be prolonged and very hard sustainable.

Received: October 15, 2015

Accepted: October 18, 2015

Milan Kubiatko

$\mathrm{PhD}$, Assistant Professor at Department of Pedagogical Studies, Faculty of Humanities, University of Zilina, Univerzitna 1, 01026 Zilina, Slovakia.

E-mail: mkubiatko@gmail.com

Website: http://www.kubiatko.eu 